\title{
Introduction to the Special Issue of Jewish History marking the 500th Anniversary of Isaac Abravanel's death
}

\author{
ABRAHAM MELAMED AND MENACHEM KELLNER \\ Haifa University, Haifa, Israel \\ E-mail: amelamed@research.haifa.ac.il \\ E-mail:kellner@research.haifa.ac.il
}

If any late medieval Jew could properly be called a Mediterranean man, it would be Don Isaac ben Judah Abravanel. Carrying the honorific title 'Don' (or 'Dom') — the third or fourth generation of his family to do so- he was born in Portugal in 1437 to a family long established there. He was forced to flee his native land upon being accused (falsely, he insisted) of participating in a conspiracy of disaffected nobles seeking to overthrow the reigning monarch. Arriving in Castile in 1483, the 46-year old political refugee quickly re-established himself financially and politically, ultimately serving as an advisor in the court of Ferdinand and Isabella. In 1492, rejecting offers that he remain in Spain, Abravanel went into exile once again, settling in Naples. Shortly after that, he was forced to flee his home a third time when a French army invaded and dethroned the monarch to whom he had attached his fortunes, to stay for a few years in Adriatic Monopoli, under Venetian control, and, eventually to end his life in 1508, on the Venetian terra firma.

It was Abravanel's belief that his family had lived in Iberia since at least $70 \mathrm{CE}$; he may even have traced his Iberian roots as far back as $586 \mathrm{BCE}-\mathrm{it}$ is not clear how seriously he took the idea that his antecedents were those nobles referred to by the prophet Ovadiah (1:20) as the exiles of Jerusalem in Sefarad. He certainly viewed himself a direct descendant of David, King of Israel, and thus probably also a progenitor of the future messianic King. Representing a family supposedly settled in Iberia for 1500 or 2000 years, he must have seen himself as rooted there at least as deeply as the Christians who sent him into exile. His view of himself and his history was certainly that of the longue durée, both looking backward to antiquity and looking forward to the messianic era.

Abravanel was not only a Mediterranean man in terms of biography and occupation; he was also deeply rooted in the culture of the region. In his work-his biblical commentaries, his independent philosophical writings, his commentaries on Maimonides' Guide of the Perplexed, the Haggadah, and Avot-he found it natural to use the ideas current in his milieu to illustrate 
his thinking. He analyzed biblical laws relating to royalty in terms of his experience with monarchs, cited Roman ideas about the division of society to explain the tri-partite priestly blessing, and brought mythical figures like Hercules and historical figures like Alexander the Great into his discussions. His messianic writings are also suffused with the sensibility of a person living through world-historical events, such as the Fall of Constantinople.

On the other hand, although his intellectual biography is that of a man living between two cultures - that of the medieval Mediterranean, on the one hand, and its Renaissance successor, on the other-he gives no indication of being conscious of the tension. He does not seem to have realized, for example, how far from Maimonides his evident fascination with reviving Neoplatonic motifs really was or just how untraditional was his political anti-monarchism, often referred to by scholars as "republicanism." Moreover, though he may have been the first prominent Jewish author to see his own books printed, his writing makes no reference to the new technology. Presumably, living through a period of great political — and geo-politicalturmoil deprived Abravanel of a sense of perspective on the cultural changes through which he was also living.

Tracing his roots to the Land of Israel, at the Eastern extremity of the Mediterranean, and seeing himself descended from "nobility" who had lived for two millennia at its Western extremity, Don Isaac ben Judah Abravanel ended his life in a variety of seaports on the Italian peninsula, deeply involved in the social, financial, and political life of every place where he settled. His legacy to future generations, however, rested principally on his writings.

In 1937, the Jewish world marked the five hundredth anniversary of Abravanel's birth with colloquia, lectures, special issues of journals, and collective volumes. It appears that the image of a proud, unbowed Jew, acknowledged by the Gentile world as both a leading intellectual and a leading financier, had special resonance for Jews facing the growing threat of Nazi Germany. The five hundredth anniversary of his death, on the other hand, is being allowed to pass with very little fanfare. This special issue of Jewish History, and the conference at the University of Haifa and the Open University of Israel (16-17 June, 2008) out of which it grew, are, as far as we know, the only academic or communal events marking this anniversary anywhere. It is an intriguing question why this was the case.

The three essays collected here relate to different aspect of Abravanel, the historical figure. On the basis of Abravanel's introductions to his biblical commentaries, Cedric Cohen-Skalli presents him as a man both deeply involved in the surrounding non-Jewish culture and self-consciously seeking to establish himself as an acknowledged leader. Ram Ben-Shalom mines those same commentaries to explore Abravanel's attitude toward one of the most 
vexed issues facing the Iberian Jewish world of his day, the status of conversos. As Ben-Shalom shows, Abravanel's broader cultural interests and commitments in no way restricted his concern for the Jewish world and is fate, which he saw through a messianic lense. Eric Lawee presents an analysis of the ways in which some of Abravanel's contemporaries read his books, their negative views, Lawee argues, conditioned by a lack of cultural knowledge and an intellectual appreciation of Abravanel's Sephardic world. To complete the issue, Jolene S. Kellner offers a bibliography of studies on Abravanel published since the year 2000 .

Taken together, then, these studies present a new and more complex picture of Abravanel as a man in whose experience the Jewish and non-Jewish worlds were inextricably intertwined. This was true not just in his economic and political activity, but in the very nature and content of his Hebrew writings on classical Jewish texts. While some of the heroism of previous portrayals may here have been lost, perhaps something more of the complex humanity of the man comes to light in these essays. Those future generations of historians who wonder why Abravanel has currently fallen so much out of fashion may find in this some food for thought.

ABRAHAM MELAMED

MENACHEM KELLNER 